\title{
Преглед публикација у форматима приступачним особама оштећеног вида
}

\author{
Ана Павловић \\ Универзитет Београду \\ Правни факултет - Библиотека \\ pavlovicana85@gmail.com
}

\begin{abstract}
Сажетак
Рад се бави публикацијама које су приступачне особама оштећеног вида, са посебним освртом на електронска издања. Особе оштећеног вида електронске публикације користе уз помоћ рачунара, који је опремљен говорним софтвером, чиме се кориснику омогућава да се образује, чита, претражује електронске каталоге и несметано ради. Текст се заснива, пре свега, на практичним искуствима библиотекара и корисника оштећеног вида.

Приступ информацијама је загарантован Конвенцијом Уједињених Нација о правима особа са инвалидитетом, као и домаћим законодавством. Тако су, поред специјализованих библиотека за ове корисничке групе, неке библиотеке оформиле службе или одељења која особама са оштећењем вида пружају библиотечке услуге.

Иако је извесно да је на пољу обезбеђивања несметаног приступа информацијама особама са оштећеним видом са појавом информационих технологија доста урађено, неопходно је да се у будућности усагласе законски прописи, библиотеке и издавачи како би се створила још повољнија клима за развој приступачних библиотека и потпуно доступних публикација за ову категорију корисника.
\end{abstract}

Кључне речи: особе оштећеног вида, електронске публикације, асистивне технологије, говорни софтвер, онлајн каталози, Брајево писмо

\section{Увод}

Особе оштећеног вида могу да користе само литературу која је њима прилагођена. Полазак у школу и обавезна школска литература су први озбиљан сусрет са књигом као извором учења за свако дете. Она деца која имају овај облик инвалидитета сусрећу се са бројним тешкоћама и када је реч о неопходним школским уџбеницима.

Израда уџбеника на Брајевом писму захтева много новца. Штампачи за њега, „ембосери“, још увек се набављају по веома високим ценама. Адаптација сликовних приказа у рељефне је можда најтежи део прилагођавања ових уџбеника, па тако најчешће постоје публикације које се задржавају на прилагођавању слова без рељефних приказа. Оно што је, са библиотекарског аспекта, такође важно знати о овим уџбеницима јесте њихова гломазност. Заузимају доста простора, па њихово складиштење и транспорт представљају значајан проблем. Примера ради, треба напоменути да једна штампана страна тзв. црног тиска износи три стране Брајевог писма.

Са појавом персоналних рачунара и развојем информационих технологија, литература постаје много доступнија особама оштећеног вида. Поред приступа дневној штампи, дописивања, коришћења електронске поште и друштвених мрежа, особе оштећеног вида могу да преузимају, размењују и читају бројне књиге, како забавног, тако и образовног карактера.

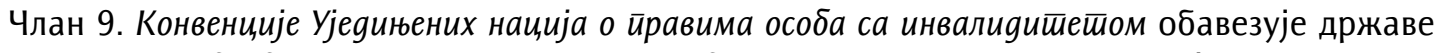
потписнице да обезбеде приступачност у свим областима друштвеног живота - јавних површина, информација, јавних установа и комуникација. То се односи и на приступачност публикација. Под књигама у приступачном формату подразумевају се оне које потпуно слеп читалац може читати или преслушавати, или које слабовид читалац може читати у увећаном формату. 
Преслушавање књига се изводи уз помоћ уређаја или софтвера за читање аудио фајлова. Рачунарски софтвер који се често користи за преслушавање je Winamp. Аудио фајл - снимак је затим као MP3-фајл доступан за преслушавање. Оваква публикација се означава као књига у аудио формату. Оне се такође могу преслушавати и уз помоћ читача екрана и синтетизатора говора, који текстуалне фајлове ишчитавају и претварају у звук. Тако се књиге у .doc и .docx форматима (програм Microsoft Word 2003, као и новије верзије) могу користити као аудио фајл. На задату команду - Insert стрелица доле - ишчитава се цео текстуални фајл. Код нас се као читач екрана најчешће користи Jaws for windows ${ }^{1}$ од серије 7.0 и даље, производ компаније Freedom scientific. Као синтетизатор говора прилагођен за српски језик на ћириличном и латиничном писму користи се AnReader, ${ }^{2}$ производ компаније AlfaNum. ${ }^{3}$ Овај софтвер може се користити за сурфовање интернетом, претраживање, писање итд. Једном речју, особа оштећеног вида може потпуно независно и самостално да користи рачунар и публикације у приступачним форматима уз примену асистивних технологија (говорних софтвера). ${ }^{4}$ Постоје и други бесплатни софтвери - читачи екрана и синтетизатори говора, али су се ова два поменута показала као најзаступљенија и најстабилнија при коришћењу. Корисник са овако опремљеним рачунаром може независно да га користи код куће, као и на радном месту.

\section{Правни оквир}

Приступачност за особе са инвалидитетом у свим областима загарантована је бројним међународним и домаћим правним документима.

Од међународних правних аката треба нарочито споменути Конвенцију Уједињених Нација о правима особа са инвалидитетом из 2006, коју је Република Србија ратификовала 2007. године. У члану 9, ст. 1 ове Конвенције, гарантује се приступачност: „1. У циљу омогућавања самосталног живота и пуног учешћа особа са инвалидитетом у свим сферама живота, државе стране уговорнице ће предузети одговарајуће мере да особама са инвалидитетом обезбеде приступ равноправно са другима физичком окружењу, превозу, информацијама и комуникацијама, укључујући информационе и комуникационе технологије и системе као и другим погодностима и услугама које су отворене односно које стоје на располагању јавности, како у урбаним тако и у руралним срединама. Те мере које укључују идентификовање и уклањање препрека и баријера за приступ, односиће се између осталог и на:

А) Зграде, путеве, превозна средства и друге погодности у затвореном и на отвореном простору, укључујући школе, стамбене објекте, здравствене објекте и радна места;

Б) Информације, комуникације и друге услуге, укључујући и електронске услуге и хитне службе". ${ }^{5}$

Од домаћих правних аката, најзначајнији је Закон о спречавању дискриминације особа са инвалидитетом. ${ }^{6}$ Њиме се гарантује равноправност особа са инвалидитетом у свим сферама друштвеног живота, што треба да омогући подједнаку приступачност како физичком окружењу, тако и информационим и комуникационим услугама.

\footnotetext{
${ }^{1}$ Freedom Scientific, Blindness Solution: JAWS: The World's Most Popular Windows Screen reader, http://www.freedomscientific.com/Products/Blindness/JAWS (preuzeto 16. 1. 2018).

${ }^{2}$ AnReader, https://anreader.alfanum.co.rs/. (preuzeto 16. 1. 2018).

${ }^{3}$ AlfaNum, https://www.alfanum.co.rs. (preuzeto 16. 1. 2018).

${ }^{4}$ Под асистивним технологијама подразумева се сваки производ, део опреме или систем, без обзира на то да ли се употребљава у изворном облику, модификован или прилагођен, који се користи да би се повећале, одржале или побољшале функционалне могућности особа са инвалидитетом - Encyclopedia of Disability (London; New Delhi: Sage Publications, 2006).

${ }^{5}$ Конвениија УН о иравима особа са инвалияишешемм, „Чл. 9 - Приступачност“, https:// www.ljudskaprava.gov.rs (преузето 22.12. 2016).

6 „Закон о спречавању дискриминације особа са инвалидитетом“, Сл. ілласник РС бр. 33 (2006).
} 
Правни документ који се непосредно односи на библиотекарство је Закон о библиотечко-информационој делатности. У чл. 5, ст. 2 и 3 као важна начела истиче: „Библиотеке под једнаким условима и без обзира на разлике обезбеђују свим грађанима остваривање људских права у домену слободе изражавања, стваралаштва, интелектуалних и других грађанских слобода као и остваривање комуникације с другим грађанима и интелектуалним добрима у земљи и иностранству. Библиотеке омогућавају грађанима приступ информацијама електронски и на друге начине". ${ }^{7}$

Одредба у чл. 29, ст. 3 овог Закона посебно се односи на особе са инвалидитетом: „Свака библиотека дужна је да обезбеди услове за остваривање права корисника библиотеке, укључујући и посебне корисничке групе као и кориснике са инвалидитетом“. ${ }^{8}$

Обавеза државе и друштвене заједнице је да даљим мерама спроведу ове важеће законске прописе и побољшају приступачност књига и библиотека свим грађанима без разлике.

\section{Информационе технологије у библиотекарству}

Бројне технолошке иновације унеле су велике промене у свакодневни живот савременог човека. Образовање, запошљавање, радни процеси, комуникација, медији и др. претрпели су корените промене.

Увођење информационих технологија у савремене библиотеке потпуно је изменило њихово функционисање. Електронске базе података и електронски каталози су данас главни инструменти којима се корисници служе за претраживање фондова. Олакшан приступ преко интернета омогућава корисницима да са удаљених локација претражују фондове библиотека и бирају литературу која им је потребна. ${ }^{9}$ Осим тога, публикације се постављају на сервере, којима корисници могу приступати са или без корисничке шифре. Могу се преузимати у целини или делимично и чувати на персоналном рачунару, или прелиставати и читати онлајн.

Употреба говорног софтвера у библиотекарству значајна је како за кориснике, тако и за библиотекаре оштећеног вида. Његовим коришћењем корисник може да претражује фонд библиотеке путем онлајн каталога, док је библиотекар у могућности да кориснику пружи одговарајуће информације и стручну помоћ при избору жељене литературе.

Тренд објављивања великог броја електронских публикација представља још једну погодност за кориснике оштећеног вида. Лакша дистрибуција, мањи трошкови издавања, поједностављено складиштење, чине да се издавачи све чешће опредељују за објављивање електронских књига и часописа.

Високошколске установе у Србији уводе правила по којима ће се све магистарске и докторске тезе, специјалистички и мастер радови, поред штампане верзије, достављати и у електронској форми на компакт диску (CD). ${ }^{10}$

Велики број публикација на овај начин постаје доступан корисницима оштећеног вида, наравно, уз услов да на рачунару поседују одговарајући говорни софтвер.

\footnotetext{
7 „Закон о библиотечко-информационој делатности“, Сл. іласник PC бр. 52 (2011), https://www.nb.rs/view_file.php?file_id=3047 (преузето 22. 12. 2016)

8 Исто.

${ }_{9}^{9}$ Stela Filipi Matutinović, Elektronski izvori informacija u nauci: značaj, vrste, dostupnost, procena vrednosti, https://www.nb.rs/view_file. php?file_id=3331 (preuzeto 22. 12. 2016)

${ }^{10} \mathrm{NaRDuS}$ - Nacionalni Repozitorijum Disertacija u Srbiji, http://nardus.mpn.gov.rs/; E-teze Univerziteta u Beogradu, http://eteze. bg.ac.rs/; PHAIDRA - Digitalni repozitorijumUniverziteta u Beogradu, https://phaidrabg.bg.ac.rs/; RCUB UviDok: Računarsko centar Univerziteta u Beogradu, „UviDok: Uvid javnosti u doktorske disertacije“, https://uvidok.rcub.bg.ac.rs/. (preuzeto 16.1. 2018)
} 


\section{Рад са корисницима оштећеног вида}

Рад са корисницима оштећеног вида требало би да заузима важно место у плановима рада сваке библиотеке. Приступ информацијама, тј. публикацијама, одвија се у великој мери у самим библиотекама или преко њихових електронских база са омогућеним приступом на даљину.

Основни предуслови које би библиотеке требало да испуњавају су техничког и кадровског карактера. Данас се прилично често говори о концепту универзалног дизајна - дизајна који ће одређени простор учинити приступачним свима без било каквих додатних прилагођавања. То значи да простор библиотеке, прилази, читаонице, тоалети, корисничка места морају бити доступни свима, без обзира да ли се ради о корисницима са инвалидитетом или без њега. ${ }^{11}$

Наиме, у читаоницама је неопходно поставити тактилне стазе до корисничких места, до места на коме се налази библиотекар, ознаке на Брајевом писму, рачунаре са говорним софтверима, увеличавајућим помагалима, лупама и др. Када је реч о кадровима, требало би обучити запослене библиотекаре у пружању услуга овим корисницима.

Библиотекари су дужни да обуче кориснике како да претражују фонд библиотеке, како да користе читаоницу и рачунар са говорним софтвером, како да читају електронске публикације на интернету или текстуалне и аудио публикације у приступачним форматима.

Претплаћивање на електронске часописе, набавка електронских књига, набавка других публикација у приступачним форматима, по могућности набавка опреме за прилагођавање публикација у приступачне формате, неопходан су чинилац у побољшању приступачности библиотека.

Неопходност поштовања међународних докумената, пре свега Конвенције УН о правима особа са инвалидитетом препознала је једна од најрелевантнијих међународних организација у библиотекарству - IFLA (International Federation of Library Asociations and Institutions Међународна федерација библиотечких удружења и установа). Она је у свом Манифесту за библиотеке које пружају услуге корисницима са тешкоћама у читању од априла 2012. препоручила свим библиотекама чланицама да међу своје редовне услуге уврсте и пружање услуга корисницима са тешкоћама у читању, при чему би обезбедиле приступачност публикација и информација, да се развој ових услуга обавља у консултацијама са појединцима са инвалидитетом и да су обучени професионалци неопходни код спровођења ових услуга. ${ }^{12}$

Термин корисници са тешкоћама у читању, који је Манифест прихватио, коректнији је јер обухвата не само особе оштећеног вида, већ и све друге особе са инвалидитетом, које приликом читања имају неке тешкоће.

У Србији постоје две специјалне библиотеке које пружају услуге корисницима оштећеног вида. То су библиотека Савеза слепих Србије „Др Милан Будимир“ и библиотека Савеза слепих Војводине „Мр Омер Маринков“. Оне у својим фондовима похрањују библиотечку грађу у аудио формату, као и на Брајевом писму, чији се број континуирано увећава.

Неке од библиотека у Србији већ су формирале одељења или службе за пружање услуга корисницима оштећеног вида. Тако је Народна библиотека Србије опремила посебну читаоницу са рачунарима и говорним софтверима као и помагалима за увеличавање за особе оштећеног вида. Универзитетска библиотека „Светозар Марковић“ је отворила Универзитетски центар за студенте са хендикепом, где корисници могу добити неопходну помоћ у коришћењу електронских публикација. Треба поменути и Правни факултет Универзитета у Београду, где такође, у оквиру библиотеке, постоји Служба за пружање услуга корисницима оштећеног вида, где

\footnotetext{
11 Драгана Милуновић, „Универзални дизајн, инклузивни дизајн или 'дизајн за све'“, Гласник Нароgне библиошеке Србије 1 (2010/2011): 210.

12 IFLA, „Манифест за библиотеке које пружају услуге корисницима са тешкоћама у читању”, https://www.nb.rs/about_us/icitem php?id=25050 (преузето 22. 12. 2016).
} 
Павловић А. „Преглед публикација у форматима приступачним особама оштећеног вида“, 67-73

студенти Факултета могу добити на коришћење уџбенике у .doc и .docx форматима, као и друга обавештења у вези са коришћењем електронских публикација и претрагом фонда.

Има још библиотека које пружају услуге корисницима оштећеног вида (Библиотека града Београда), али је њихов број још увек мали и недовољан. Треба много радити на приступачности библиотека и њихових услуга за све кориснике без дискриминације и под једнаким условима, како би потребе ових особа за књигом биле задовољене.

\section{Електронске публикације за особе оштећеног вида}

Електронске публикације су умногоме олакшале приступ информацијама, учење и образовање особа оштећеног вида. Треба истаћи да нису све електронске публикације приступачне овим особама. Наиме, говорни софтвер није у могућности да препознаје и чита све електронске формате.

Публикације које говорни софтвер може да, уз задавање одговарајуће команде, претвори у звучну информацију, морају бити у адекватном формату. Особе оштећеног вида у Србији могу да читају само фајлове у Microsoft office Word (.doc и .docx) форматима, којима се може приступити помоћу програма Microsoft office Word 2003 и новијих верзија. Овакве публикације су лаке за читање и лако претраживе. Корисник може на њима да бележи своје коментаре, додаје и брише, по потреби, делове текста. Тако нпр. Правни факултет Универзитета у Београду студентима оштећеног вида уступа своје уџбенике у .doc и .docx форматима, чиме им је студирање потпуно приступачно и прилагођено.

Публикације у PDF формату се отварају помоћу Adobe Acrobat Reader-a 9.0 и новијих верзија. Особе са оштећењем вида тешко читају овакве публикације јер се "теже“ крећу по тексту, фајл се доста дуго отвара и може се десити чак и да текст уопште не буде читљив, уколико се ради о скенираном тексту, односно слици (JPG фајл), која је пребачена у PDF формат. Оваква датотека се мора конвертовати у .doc формат помоћу OCR софтвера. ${ }^{13}$ За конвертовање се углавном користе Abby FineReader 11 и новији.

Нешто ређе се електронске публикације појављују и у .txt формату, који се најчешће чита помоћу програма Word pad.

Нажалост, издавачи се не одлучују на објављивање електронских издања публикација јер постоји бојазан од злоупотреба ауторских права, евентуалног неовлашћеног уступања, копирања и преснимавања ових издања. ${ }^{14}$ Тако особе оштећеног вида у нашој земљи често остају ускраћене за овакве публикације.

Употреба електронских публикација у аудио формату односи се на коришћење већ ишчитаних публикација, које се снимају у MP3 и MWA формату. Овакве публикације корисник може читати, односно преслушавати, на било ком MP3 плејеру, рачунару и другом погодном уређају.

Предност ових издања је неспорност ауторских права и мања могућност злоупотребе у смислу копирања и прештампавања.

\section{Закључак}

Кратак преглед стања у области приступачности публикација и библиотека уопште за кориснике оштећеног вида може створити приближну представу чиме се располаже и шта треба унапредити.

\footnotetext{
${ }^{13}$ Optical character recognition.

14 „Закон о ауторском и сродним правима“, Сл. іласник PС бр. 104 (2009), 99 (2011), 29 (2016) - Одлука УС, http://www.paragraf. rs/propisi/zakon_o_autorskom_i_srodnim_pravima.html (преузето 22. 12. 2016).
} 
Преглед оквирних међународних и домаћих правних докумената говори да у друштвеној заједници постоји свест о неопходности поштовања људских права свих грађана без разлике, па тако и људског права особа са инвалидитетом на приступ информацијама.

Практична искуства библиотекара и корисника оштећеног вида, која су централни део овог рада, приказала су како данашњи корисник функционише, чиме се служи и шта му треба још учинити приступачним. Сложеност говорног софтвера и некомпатибилност рачунарских програма, представљају највеће тешкоће у коришћењу електронских публикација. Неприступачни формати и интернет презентације такође онемогућавају слободан приступ информацијама.

Законодавац би требало да ради на усаглашавању домаћих и међународних правних аката у овој области и успостављању механизама за њихову примену. Консултације са удружењима особа са инвалидитетом и библиотекарима који се сусрећу са посебним групама корисника допринеле би стварању повољне климе за развој приступачних библиотека и потпуно доступних публикација. Издавачи су такође неопходан чинилац у побољшању приступачности публикација у смислу да ће лакше уступати своја издања без бојазни од злоупотреба ауторских права, што је такође неопходно уредити законом.

\section{Литература и извори:}

1. AlfaNum. https://www.alfanum.co.rs. (preuzeto 16. 1. 2018).

2. AnReader. https://anreader.alfanum.co.rs/. (preuzeto 16. 1. 2018).

3. Encyclopedia of Disability. London; New Delhi: Sage Publications, 2006.

4. E-teze Univerziteta u Beogradu. http://eteze.bg.ac.rs/ (preuzeto 16. 1. 2018).

5. Filipi Matutinović, Stela. Elektronski izvori informacija u nauci: značaj, vrste, dostupnost, procena vrednosti. https://www.nb.rs/view_file.php?file_id=3331 (preuzeto 22.12. 2016).

6. Freedom Scientific. Blindness Solution: JAWS: The World's Most Popular Windows Screen reader. http:// www.freedomscientific.com/Products/Blindness/JAWS (preuzeto 16. 1. 2018)

7. IFLA. „Manifest za biblioteke koje pružaju usluge korisnicima sa teškoćama u čitanju”. https://www. nb.rs/about_us/icitem.php?id=25050 (preuzeto 22. 12. 2016).

8. Konvencija UN o pravima osoba sa invaliditetom. https://www.ljudskaprava.gov.rs (preuzeto 22. 12. 2016).

9. Milunović, Dragana. „Univerzalni dizajn, inkluzivni dizajn ili ,dizajn za sve”". Glasnik Narodne biblioteke Srbije 1 (2010/2011): 209-214.

10. NaRDuS - Nacionalni Repozitorijum Disertacija u Srbiji. http://nardus.mpn.gov.rs/ (preuzeto 16. 1 2018).

11. PHAIDRA - Digitalni repozitorijumUniverziteta u Beogradu. https://phaidrabg.bg.ac.rs/ (preuzeto 16. 1. 2018).

12. RCUB UviDok: Računarsko centar Univerziteta u Beogradu. „UviDok: Uvid javnosti u doktorske disertacije". https://uvidok.rcub.bg.ac.rs/. (preuzeto 16. 1. 2018).

13. „Zakon o autorskom i srodnim pravima“. Službeni glasnik RS br. 104 (2009), 99 (2011), 29 (2016) Odluka US. http://www.paragraf.rs/propisi/zakon_o_autorskom_i_srodnim_pravima.html (preuzeto 22. 12. 2016).

14. „Zakon o bibliotečko-informacionoj delatnosti“. Službeni glasnik RS br. 52 (2011). https://www.nb.rs/ view_file.php?file_id=3047 (preuzeto 22.12. 2016).

15. „Zakon o sprečavanju diskriminacije osoba sa invaliditetom“. Službeni glasnik RS br. 33 (2006). 


\title{
Overview of Publications in Formats Accessible to Visually Impaired People
}

\begin{abstract}
Summary
This paper deals with publications accessible to visually impaired persons, with special reference to electronic editions. People with visual impairments use electronic publications with the help of computers equipped with voicebased screen reader and text to speech software, allowing users to educate themselves, read, search electronic catalogues and work without obstacles. The text is based primarily on the practical experience of librarians and visually impaired users.

Access to information is guaranteed by the United Nations Convention on the Rights of Persons with Disabilities, as well as domestic legislation. Thus, in addition to specialized libraries for these groups of users, there are some libraries that have established sections or departments to provide library services for visually impaired persons. Although it is certain that, with the emergence of information technologies, much has been done in the field of providing people with visual impairments with unhindered access to information, it is still necessary to harmonize legal regulations, libraries and publishers, in order to create more favorable climate for the development of approachable libraries and completely available publications for this category of users.
\end{abstract}

Keywords: visually impaired persons, electronic publications, assistive technology, text to speech software, online catalogues, Braille alphabet

Примљено: 23. децембра 2016. Исправке рукописа: 16. јануара 2018. Прихваћено за објављивање: 24. јануара 2018. 


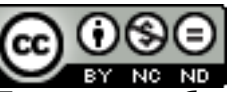

Преглед публикација у форматима приступачним особама оштећеног вида bу Ана Павловић is licensed under a Creative Commons Attribution-NonCommercial-NoDerivatives 4.0 International License. 